\title{
ANALISIS SISTEM ANTRIAN PADA DIREKTORAT KEUANGAN UNIVERSITAS HALMAHERA
}

\section{Analysis Of The Queue System In The Directorate Of Finance Of Halmahera University}

\author{
Meidy Kaseside ${ }^{1 *}$, Ravenska Tiffany Lahengking², Mario Nikolaus Dalengkade ${ }^{3}$ \\ ${ }^{1,2,3}$ Program Studi Matematika, Fakultas Ilmu Alam dan Teknologi Rekayasa Universitas Halmahera \\ Jln. Wari Raya, Tobelo, Halmahera Utara 97762, Maluku Utara, Indonesia
}

e-mail corresponding author: kasesidemeidy@gmail.com

\begin{abstract}
Abstrak: Sistem antrian yang diterapkan di Direktorat Keuangan Universitas Halmahera merupakan single arrivals. Dimana sistem tersebut hanya memiliki satu unit server. Dari hasil pengamatan memperlihatkan setiap semester sewaktu pembayaran SPP maupun pembayaran lainnya, mengakibatkan panjangnya antrian yang terjadi. Fenomena antrian dan waktu layanan yang terjadi di Direktorat Keuangan Universitas Halmahera dapat dijabarkan menggunakan suatu konsep matematika mengenai distribusi peluang. Hasil uji Poisson memperlihatkan 0,03 $\leq$ 0,9982 sehingga, proses antrian di Direktorat Keuangan Universitas Halmahera berdistribusi Poisson. Sedangkan analisis waktu layanan yakni 4,606 $>0,352$ maka, disimpulkan waktu layanan tidak berdistribusi eksponensial. Penyebab di tolaknya waktu layanan karena $h_{l}$ sejak pukul 09.00-12.00 tidak ada antrian saat layanan di kantor Direktorat Keuangan.
\end{abstract}

Kata Kunci: Antrian, Distribusi Poisson, Distribusi Eksponensial.

\begin{abstract}
The queuing system applied at the Directorate of Finance of the University of Halmahera is single arrivals. Where the system has only one server unit. The observation shows that each semester during SPP payment or other payments, resulting in long queues that occur. The phenomenon of queuing and service time that occurs at the Directorate of Finance of the University of Halmahera can be described using a mathematical concept of probability distribution. Poisson test results showed $0.03 \leq 0.9982$ so that the queuing process at the Directorate of Finance of the University of Halmahera was Poisson distribution. While the analysis of service time is $4.606>0.352$, it is concluded that service time has no exponential distribution. The reason for the decline in service time is because $h_{1}$ since 09.00-12.00 there is no queue when the service is in the office of the financial directorate.
\end{abstract}

Keywords: Queue, Poisson Distribution, Exponential Distribution.

\section{PENDAHULUAN}

Antrian dan layanan lazimnya ditemukan pada suatu fasilitas pelayanan yang dapat dijabarkan menggunakan suatu konsep matematika mengenai distribusi peluang [1,2]. Fenomena mengenai antrian dan waktu layanan merupakan distribusi identik serta independen [1]. Disamping itu antrian juga merupakan suatu proses renewal, sedangkan waktu layanan mengacu pada distribusi eksponensial atau deterministik (Poisson) [3].

Apabila suatu fenomena antrian mengikuti pola distribusi Poisson jika mengikuti aturan sebagai berikut $[3,4,5]$ :

a) Tidak terjadi layanan ganda dalam satu waktu yang sama.

b) Proses antrian bersifat acak.

c) Rerata jumlah antrian per interval waktu telah diketahui sebelumnya. 
d) Apabila interval waktu dibagi ke dalam interval yang lebih kecil, sehingga pernyataan tersebut harus memenuhi : 1) Probabilitas antrian yakni kecil dan konstan; 2) Probabilitas antrian (satu atau lebih antrian) selama interval waktu, harganya sangat kecil sehingga mendekati nol; 3) Jumlah antrian pada selang interval waktu tertentu tidak bergantung pada interval waktu sebelum dan sesudah layanan antrian.

Sedangkan fenomena waktu layanan mengikuti pola eksponensial jika memenuhi aturan sebagai berikut.

a) Waktu layanan bersifat acak.

b) Waktu layanan selanjutnya independen terhadap waktu layanan sebelumnya.

c) Waktu layanan dipengaruhi oleh jumlah antrian.

Baru-baru ini [6] mengkaji penerapakan distribusi Poisson dan eksponensial guna menghitung

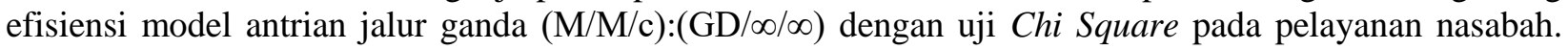
Dalam laporan tersebut harga distribusi Poisson yakni $x_{\text {hitung }}^{2}=3,95$ dan $x_{\text {tabel }}^{2}=12,59$, serta harga distribusi ekponensial $x_{\text {hitung }}^{2}=0,35, x_{\text {tabel }}^{2}=12,59$. Dari kedua distribusi tersebut dinyatakan $H_{0}$ diterima atau dengan kata lain setiap server memiliki waktu sibuk rata-rata 82,48\% dari jam kerja. Pihak lain [7] melaporkan kajian model antrain dalam pembuatan Surat Ijin Mengemudi (SIM) menggunakan distribusi Poisson yakni $x_{\text {hitung }}^{2}=0,014, x_{\text {tabel }}^{2}=0,711$ sehingga hipotesis $H_{1}$ diterima, karena $x_{\text {hitung }}^{2} \leq x_{\text {tabel }}^{2}$. Sedangkan distribusi eksponensial $x_{\text {hitung }}^{2}=1,979, x_{\text {tabel }}^{2}=0,711$, maka kriteria pengambilam keputusan yakni menolak $H_{0}$ untuk loket 1 karena $x_{\text {hitung }}^{2}>x_{\text {tabel }}^{2}$ sama halnya dengan loket II, tapi menerima $H_{0}$ untuk loket III karena $x_{\text {hitung }}^{2}=0,368$, dan $x_{\text {tabel }}^{2}=0,711$.

Menelaah kembali mengenai uraian distribusi Poisson dan eksponensial serta hasil penelitian terdahulu di atas, maka penelitian mengenai sistem antrian yang terjadi di Direktorat Keuangan Universitas Halmahera sangat penting untuk diteliti. Karena penerapan sistem antrian di Direktorat Keungan Universitas Halmahera yakni single arrivals, mengakibatkan terjadinya antrian yang panjang berdampak pada tidak efisiennya waktu pelayanan. Dari pada itu, hasil penelitian ini nantinya akan menjadi dasar pengambilan kebijakan untuk sistem yang diterapkan di Direktorat Keuangan Universitas Halmahera.

\section{METODOLOGI}

\subsection{Metode Penelitian}

Metode yang digunakan dalam penelitian ini yakni deskriptif, yaitu suatu metode penelitian yang menginterprestasi objek sesuai dengan apa adanya. Penelitian tersebut sering diungkapkan sebagai noneksperimen, karena peneliti tidak melakukan manipulasi variabel penelitian. Sehingga dengan menggunakan metode tersebut memungkinkan peneliti menghubungkan variabel dan menguji hipotesis. Pelaksanaan penelitian ini yakni di Direktorat Keuangan Universitas Halmahera, dengan lamanya penelitian ialah empat hari terhitung sejak 04-03-2019 hingga 07-03-2019.

\subsection{Prosedur Penelitian}

Uraian prosedur pengambilan dan analisis data dalam penelitian ini yakni:

1. Menentukan model antrian. Antrian dalam penelitian ini yakni antrian secara individu (single arrivals).

2. Menghitung rerata jumlah antrian dan waktu layanan.

3. Menghitung rerata waktu antrian, menggunakan persamaan distribusi Poisson $[3,4]$ yakni:

$$
P(n)=\frac{\lambda^{n} e^{-\lambda}}{n !}, n=0,1,2,
$$


Dengan $P(n)=$ probabilitas $n$ waktu antrian, $n=$ jumlah orang per satuan waktu, $\lambda=$ rerata waktu mengantri, $e=2,71828$ (Bilangan Navier).

4. Menghitung waktu pelayanan antrian, menggunakan persamaan eksponensial $[3,4]$ yakni:

$$
P(t)=\mu e^{-\mu t}, t \geq 0
$$

5. Uji kesesuaian Poisson. Uji Poisson digunakan untuk menghitung $\chi^{2}$ dari data $h_{1}, h_{2}, h_{3}, h_{4}$ (jumlah pengambilan sampel) dari data jumlah antrian menggunkan persamaan (3) [3,4]:

$$
\chi^{2}=\sum_{i=1}^{K} \frac{\left(\lambda_{i}-\bar{\lambda}\right)}{\bar{\lambda}}
$$

Dengan $K=$ banyaknya data pengamatan, $\lambda_{i}=$ jumlah antrian, $\bar{\lambda}=$ rerata jumlah antrian. Guna mendapat harga $\chi^{2}$ dari harga kecepatan antrian dengan hipotesisi sebagai berikut.

$H_{1}=$ Kecepatan antrian mengikuti distribusi Poisson.

$H_{0}=$ Kecepatan antrian tidak mengikuti distribusi Poisson .

Sehingga kriteria dalam pengambilan keputusan yakni menerima harga kecepatan antrian distribusi Poisson apabila $\chi^{2}$ hitung $\leq \chi^{2}$ tabel dalam hal lain keputusan ditolak.

6. Uji kesesuaian eksponensial. Uji eksponensial digunakan untuk mencari $\chi^{2}$ dari data waktu layanan yakni $h_{1}, h_{2}, h_{3}, h_{4}$ (hari), dengan menggunakan persamaan (4.) [3,4]:

$$
\chi^{2}=\sum_{i=1}^{K} \frac{\left(\mu_{i}-\mu_{\text {harapan }}\right)^{2}}{\mu_{i}}
$$

Dengan $K=$ banyak data pengamatan, $\mu_{i}=$ rerata pelayanan waktu ke $-i, \mu_{\text {harapan }}=$ rerata pelayanan harapan waktu ke- $i$. Untuk menemukan harga $\chi^{2}$ dari waktu layanan dengan menggunakan hipotesis sebagai berikut.

$H_{1}=$ Waktu layanan tidak mengikuti distribusi ekponensial.

$H_{0}=$ Waktu layanan mengikuti distribusi eksponensial.

Sehingga kriteria dalam pengambilan keputusan yakni menerima data rerata palayanan mengikuti distribusi eksponensial, apabila $\chi^{2}$ hitung $\leq \chi^{2}$ tabel dalam kondisi sebaliknya keputusan ditolak.

\section{HASIL DAN PEMBAHASAN}

\subsection{Jumlah Antrian}

Luaran analisis data antrian yang dipaparkan dalam Tabel 1 , yakni rerata $\lambda\left(h_{i}\right)$ menyatakan tingkat kedatangan hari ke- $i$ untuk $i=1,2,3,4$ per satuan waktu.

Tabel 1. Rerata Jumlah Antrian

\begin{tabular}{ccccc}
\hline Hari/Waktu & $\boldsymbol{h}_{\boldsymbol{1}}$ & $\boldsymbol{h}_{\mathbf{2}}$ & $\boldsymbol{h}_{\mathbf{3}}$ & $\boldsymbol{h}_{\boldsymbol{4}}$ \\
\hline $\mathbf{0 9 . 0 0}-\mathbf{1 0 . 0 0}$ & 0 & 14 & 5 & 8 \\
\hline $\mathbf{1 0 . 0 1 - 1 1 . 0 0}$ & 0 & 7 & 6 & 19 \\
\hline $\mathbf{1 1 . 0 1 - 1 2 . 0 0}$ & 0 & 9 & 2 & 6 \\
\hline $\mathbf{1 4 . 0 0 - 1 5 . 0 0}$ & 15 & 5 & 4 & 10 \\
\hline Rerata $\boldsymbol{\lambda}$ & 3,75 & 8,75 & \\
$\boldsymbol{\lambda}\left(\boldsymbol{h}_{\boldsymbol{i}}\right)=\frac{\boldsymbol{\lambda}_{\mathbf{1}}+\boldsymbol{\lambda}_{\mathbf{2}}+\boldsymbol{\lambda}_{\mathbf{3}}+\boldsymbol{\lambda}_{\mathbf{4}}}{\boldsymbol{n}}=\frac{\mathbf{2 6 , 5}}{\mathbf{4}}=\mathbf{6 , 6 2 5}$ mahasiswa $/ \mathbf{6 0}$ menit
\end{tabular}

Setelah diketahuinya harga $\lambda\left(h_{i}\right)$ dalam Tabel 1, maka perhitungan rerata waktu antrian dilanjutkan 
menggunakan distribusi Poisson Persamaan (1) menghasilkan:

$$
P(n)=\frac{6,625^{4} \times 2,71828^{(-6,625)}}{4}=\frac{1926,387 \times 0,001}{24}=0,08
$$

Hasil yang diperolah dengan menerapkan Persamaan (1) yakni 0,08. Hasil ini mengartikan bahwa rerata jumlah antrian per satuan waktu. Hasil penelitian ini memiliki kesamaan dengan [7] yang mengkaji model antrian pada pembuatan SIM.

\subsection{Waktu Layanan}

Luaran analisis waktu layanan disajikan dalam tabel 2 , yakni rerata $\mu\left(h_{i}\right)$ menyatakan waktu layanan yang sedang terjadi persatuan waktu dimana $i=1,2,3,4$ (jumlah data pengamatan). Sedangkan nilai $\mu_{\text {harapan }}$ diperoleh dengan menggunakan persamaan (4) dimana $t=1$.

Tabel 2. Rerata Waktu Layanan dan Nilai $\mu_{\text {harapan }}$

\begin{tabular}{ccccc}
\hline Hari / Waktu & $\boldsymbol{h}_{\boldsymbol{1}}$ & $\boldsymbol{h}_{\boldsymbol{2}}$ & $\boldsymbol{h}_{\mathbf{3}}$ & $\boldsymbol{h}_{\boldsymbol{4}}$ \\
\hline $\mathbf{0 9 . 0 0}-\mathbf{1 0 . 0 0}$ & 0 & 2,35 & 2,4 & 2,6 \\
\hline $\mathbf{1 0 . 0 1}-\mathbf{1 1 . 0 0}$ & 0 & 1,71 & 1,7 & 2 \\
\hline $\mathbf{1 1 . 0 1}-\mathbf{1 2 . 0 0}$ & 0 & 2,33 & 2,7 & 5,7 \\
\hline $\mathbf{1 4 . 0 0}-\mathbf{1 5 . 0 0}$ & 2,73 & 2 & 1,5 & 1,8 \\
\hline Rerata $\boldsymbol{\mu}$ & 1,465 & 0,476 & 0,481 & 0,330 \\
\hline $\boldsymbol{\mu}_{\text {harapan }}$ & 0,338 & 0,295 & 0,297 & 0,237 \\
\hline
\end{tabular}

Tabel 2 memperlihatkan $h_{l}$ memiliki harga rerata dan $\mu_{\text {harapan }}$ yang terbesar yakni secara berturutturut 1,465 serta 0,338. Hal ini disebabkan karena sejak pukul 09.00 hingga 12.00 tidak adanya antrian saat layanan. Sedangkan untuk $h_{2}, h_{3}$, dan $h_{4}$ berikutnya pada Tabel 2 menunjukkan terjadinya waktu layanan sejak pukul 09.00 hingga 15.00 .

\subsection{Uji Kesesuaian Poisson}

Pengujian kesesuaian Poisson dalam penelitian ini guna mencari nilai $x^{2}$. Untuk mencari nilai tersebut langkah pertama yakni dengan menentukan harga kecepatan antrian menggunakan persamaan $\lambda\left(h_{i}\right) / 60$ menit $\mathrm{x}$ interval waktu antrian, maka didapat harga kecepatan antrian yang dirangkum pada Tabel 3 .

Tabel 3. Harga Kecepatan Antrian

\begin{tabular}{ccccc}
\hline Hari & $\boldsymbol{h}_{\boldsymbol{1}}$ & $\boldsymbol{h}_{\mathbf{2}}$ & $\boldsymbol{h}_{\mathbf{3}}$ & $\boldsymbol{h}_{\mathbf{4}}$ \\
\hline $\boldsymbol{\lambda}$ & 0,016 & 0,036 & 0,017 & 0,042 \\
\hline
\end{tabular}

Dari Tabel 3, harga kecepatan antrian tertinggi yakni pada $h_{4}$ sebesar 0,042 orang per menit. Sedangkan terendah pada $h_{1}$ sebesar 0,016 orang per menit. Pengujian selanjutnya yakni mencari $x^{2}$ dari data yang ditunjukan oleh Tabel 3 menggunakan Persamaan (3) menghasilkan $x^{2}=0,029^{2} / 0,028=0,03$.

Berdasarkan perhitungan $x^{2}$ yang telah diketahui batas harga kritis sebesar 0,03 , pengujian dilanjutkan kembali menggunakan taraf nyata $\alpha=0,05$ dan jumlah data pengamatan dikurangi satu $(k=$ $(4-1)=3$ ), maka $x^{2}$ tabel $=0,9982$. Sehingga hipotesis diterima yakni menerima $H_{1}$, karena $x_{\text {hitung }}^{2} \leq$ $x_{\text {tabel }}^{2}$ dengan pernyataan lain $0,03 \leq 0,992$. Hasil penelitian ini sejalan dengan peneliti terdahulu yang mengkaji Model antrian pembuatan Surat Ijin Mengemudi (SIM) dan model antrian pada sistem pembayar $[6,7]$.

\subsection{Uji Kesesuaian Eksponensial}

Pengujian eksponesial ditujukan guna mencari harga $x^{2}$ dari data waktu layanan $h_{l}, h_{2}, h_{3}$, dan $h_{4}$. Data hasil perhitungan yang ditunjukan oleh Tabel 2 khususnya harga rerata $\mu$ dan $\mu_{\text {harapan }}$ merupakan data kecepatan layanan. Sehingga dengan data kecepatan tersebut dimasukan ke dalam Persamaan (4) 
menghasilkan $x^{2}=1,345 / 0,292=4,606$. Berdasarkan hasil pengujian Persamaan (4) untuk $x^{2}=4,606$, maka pengujian dilanjutkan kembali dengan taraf nyata $\alpha=0,05$ dan menggunakan jumlah data dikurangi satu $(k=(4-1)=3)$ menghasilkan $x^{2}$ tabel $=0,352$. Sehingga hipotesis $H_{0}$ ditolak, karena $x_{\text {hitung }}^{2}>$ $x_{\text {tabel }}^{2}$ atau 4,606 $>0,352$. Ditolaknya data waktu layanan karena, dalam penelitian ini $h_{l}$ sejak pukul 09.0012.00 tidak ada antrian saat layanan di kantor Direktorat Keuangan. Argument yang dituangkan dari kalimat sebelumnya berbanding terbalik dengan hasil penelitian oleh $[5,7,8,9]$.

\section{KESIMPULAN}

Berdasarkan uraian hasil penelitian di atas, maka model antrian di Direktorat Keuangan Universitas Halmahera yakni secara individu. Disamping itu kecepatan antrian yang tertinggi pada $h_{4}$ sebesar 0,042 orang per menit. Selanjutnya dari hasil uji kesesuaian Poisson menunjukkan harga 0,03 $\leq 0,9982$ mengindikasikan harga kecepatan antrian berdistribusi Poisson. Sedangkan uji eksponensial berdasarkan data layanan waktu menunjukkan harga 4,606 >0,352 mengindikasikan bahwa data waktu layanan tidak berdistribusi eksponensial. Walaupun dari hasil penelitian menunjukan efisiensi waktu layanan tidak berdistribusi eksponensial, tapi kedepannya Direktorat Keuangan Universitas Halmahera agar melakukan perubahan sistem antrian tunggal menjadi sistem antrian ganda.

\section{DAFTAR PUSTAKA}

[1] Sugito., \& Mukid, M. A., Distribusi Poisson dan Distribusi Eksponensial Dalam Proses Stokastik. Media Statistika, vol. 4, no. 2, pp. 113-120, 2011.

[2] Hillier, F. S., \& Lieberman, G. J., Introduction To Operations Research $7^{\text {nd }}$ Edition. McGraw-Hill, Boston: 2001.

[3] Kulkarni, V. G., Modeling, Analysis, Design, and Control of Stochastic Systems. Springer-Verlag, New York: 1999.

[4] Gross, D., Shortle, J. F., Thompson, J. M., \& Harris, C. M., Fundamentals of Queueing Theory Fourth Edition. John Wiley end Sons, Inc. Canada: 2008.

[5] Wijayanti, D. E., Algoritma Penentuan Ukuran Sampel Eksak Untuk Distribus Normal, Distribusi Poisson Dan Dua Distribusi Binomial Dalam Model Keluarga Eksponensial. Jurnal Konvergensi, vol. 4, no. 1, pp. 27-40, 2014.

[6] Arina, R. S., Sinulingga, H. U \& Ariswoyo, S., Analisis Sistem Antrian Pelayanan Nasabah Di Pt. Bank Negara Indonesia (Persero) Tbk Kantor Cabang Utama Usu. Saintia Matematika, vol. 02, no. 03, pp. 277-287, 2014.

[7] Bahar, M. S., Mananohas, M. L., Montolalu \& Chriestie E. J. C., Model Sistem Antrian dengan Menggunakan PolaKedatangan dan Pola Pelayanan Pemohon SIMdi Satuan Penyelenggaraan Adminstrasi SIM ResortKepolisian Manado. deCartesian, vol. 7, no. 1, pp. 15-21, 2018.

[8] Sumarno, M.., Langi, Y \& Latumakulita, Luther., Model Antrian pada Sistem Pembayaran di Golden Pasar Swalayan Manado. deCartesian, vol. 4, no. 2, 180-187, 2015.

[9] Astria, L., Sitepu, H. R \& Darnius, O., Analisa Tingkat Kepuasan Masyarakat Terhadap Proses Pelayanan Pembuatan SIM (Surat Izin Mengemudi) Di Satlantas Polres Tapanuli Selatan. Saintia Matematika, vol. 1, no. 5, pp. 435-444, 2013. 
Volume 1 Nomor 2 | Desember 2019 